\title{
Analysis of the Effect of Earning Per Share (EPS), Return On Assets (ROA), Price Earning Ratio (PER), and Debt to Equity Ratio (DER) on Stock Prices in Property, Real Estate, Construction and Building Companies Registered on the Indonesia Stock Exchange in 2016-2018
}

\author{
Wikan Budi Utami ${ }^{1}$, Muhammad Tho'in ${ }^{2}$ \\ Institut Tehnologi Bisnis AAS Indonesia ${ }^{1,2}$ \\ \{budiutamiwikan@gmail.com ${ }^{1}$, thoinsyakira@yahoo.com²
}

\begin{abstract}
This study aims to determine the effect simultaneously and partially between EPS, ROA, PER and DER on stock prices on the Indonesia Stock Exchange in 2016-2018.Data collection method in this research is documentation method. The populations in this study are property, real estate, construction and building companies listed on the Indonesia Stock Exchange in 2016-2018. Sampling was done by purposive sampling method. This research variable consists of EPS, ROA, PER, DER and stock price as the dependent variable.The conclusion is that simultaneously EPS, ROA, PER and DER affect the stock price. Partially EPS and PER signicantly influence stock prices while ROA and DER have no effect on stock prices. The coefficient of determination $\left(\mathrm{R}^{2}\right)$ is $47.9 \%$ which means that EPS, ROA, PER and DER can affect the Share Price by $47.9 \%$ while the remaining $52.1 \%$ is influenced by other factors not examined in this study.
\end{abstract}

Keywords: Stock Price, EPS, ROA, PER, DER

\section{Introduction}

The movement of shares in the business sector Property, Real Estate, Construction and Building is the main attraction for investors. Before investing an investor must first conduct an assessment of the stock price as a fundamental step, so that the investor is not trapped in an adverse situation. Share price is one indicator that shows success in managing a company. High stock prices will provide benefits for a company in the form of a good image and good capital gains so that the company will easily obtain funds from outside the company. Share price itself can be influenced by various factors some of which are Earning Per Share (EPS), Return On Assets (ROA), Price Earning Ratio (PER) and Debt To Equity Ratio (DER).

Earning Per Share (EPS) is a comparison between the amount of net profit received by the investor and the number of shares. The higher the EPS value, the higher the profits to be gained by shareholders (Safitri, 2013). EPS value can influence significantly or not 
significantly as in research conducted by Safitri (2013), and Muksal (2016) states that EPS partially affects stock prices, whereas from research conducted by Hijriah (2007) EPS has no effect on prices stock.

Return on assets (ROA) or profitability is a financial ratio that can be used to measure how much the company's ability to generate corporate profits (Muksal, 2014). The greater the value of ROA in the company, the better the company will be, because the level of profits obtained by the company from managing its assets is greater. This can increase investor confidence in the company. ROA affects stock, this is as in previous studies conducted by Muksal (2016), stating that ROA partially significantly influences stock prices in companies, whereas in research conducted by Safitri (2013) and Hijriah (2007) is different from Other previous research is that ROA has no effect on firm prices.

Price Earning Ratio (PER) according to Hermawati \& Hidayat in (Darmadji and Fakrudin, 2011: 156) is a depiction of market appreciation of the company's ability to generate corporate profits. In this ratio can describe the level of investor confidence in the company. If the PER value of the company is getting higher, investors will trust the company more, with this the stock price will be more expensive. This can be supported from research conducted by previous researchers, Safitri (2013) and Hijriah (2007), which states that PER significantly affects the stock price of a company.

Debt to Equity Ratio (DER) is the total debt of the company to the total assets owned by the company, the total debt in question is the total current debt and long-term debt (Brigham \& Houston, 2006: 143). Basically, an investor would prefer a company with a low debt ratio because the lower the debt ratio, the greater the level of losses that will be experienced by investors if the company is liquidated. High and low DER will affect investors in investing their shares, so this will affect the company's stock price. The results of previous studies conducted by Safitri (2013) stated that DER has no effect on stock prices while research conducted by Munira, Mira et al (2017) states that DER has a very significant influence on company stock prices.

Based on the background of the differences in previous research that has been done, this study takes the title of "Analysis of the Effects of Earning Per Share (EPS), Return On Assets (ROA), Price Earning Ratio (PER), and Debt to Equity Ratio (DER) Against Share Prices of Property, Real Estate, Construction and Building Companies Listed on the Indonesia Stock Exchange in 2016 to 2018.

\section{Literature Review}

\subsection{Prior Research}

Almas Hijriah, 2007 with the title research on the Effect of Fundamental Factors and Systematic Risk on Property Stock Prices on the JSX, concluded that ROA, DER, EPS and Systematic Risk partially had no effect on stock prices while ROE, PER and BV partially had a high influence significant to stock prices. Safitri Abied Lutfi Research, 2013, entitled The Effect of Earning Per Share, Price Earning Ratio, Return On Assets, Debt to Equity Ratio and Market Value Added to Stock Prices in JII 2008-2011 draw conclusions that simultaneously EPS, PER, ROA, DER \& MVA affect the stock price

Research with the title Analysis of Factors Affecting Sharia Stock Prices A Study on the Secondary Market JII by Muksal (2016) concluded that ROA \& EPS partially had a significant positive effect on stock prices, DER \& BV had no effect on stock prices, trading 
volume had an influence significant negative effect on stock prices. Research with the title Effect of ROE and DER on Paper Company Stock Prices on the Indonesia Stock Exchange by Munira, Mira, Endang Etty Merawati, Shinta Budi Astuti, (2017) draws the following conclusions: ROE partially has no significant effect on stock prices, DER in a partial has a significant influence on stock prices. Simultaneously, ROE and DER have a significant influence on stock prices.

\subsection{Earning Per Share (EPS)}

Earning Per Share (EPS) or share income per share is a profit obtained by the company which will later be given to shareholders from each share owned (Fahmi, 2017: 96). The greater the EPS value of a company, the greater the level of profits to be obtained by the company's shareholders. With the high value of the company's profits, this will be an attraction for investors to invest in the company. This will result in an increase in the company's stock price.

\subsection{Return on Assets (ROA)}

Return On Assets (ROA) is one indicator that can be used to see the extent of the ability of company assets in generating corporate profits (Tandelilin, 2007: 240). High or low value of ROA in a company depends on how the company's policies in running or using assets owned. An asset if used as well and efficiently as possible it will produce a high ROA value and vice versa. A high ROA value will attract investors to buy shares, this will affect the stock price which will be higher.

\subsection{Price Earning Ratio (PER)}

Price Earning Ratio (PER) is the ratio between the stock market price per sheet with the profit share per sheet (Fahmi, 2017: 97). Subana (2001: 23) states that the higher the value of the PER ratio indicates that investors have good expectations of the development of a company, so that stock prices will increase. PER of a company with a high value indicates that the company has good growth prospects and the risk will be relatively low. It can be concluded that the higher the value of PER, the profits generated by the company will also increase.

\subsection{Debt to Equity Ratio (DER)}

According to Darsono (2005: 54) Debt to Equity Ratio (DER) is a ratio that shows the percentage of the need for funds provided by shareholders to lenders in a company. DER shows how much debt a company has and how the company can cover its debt burden. If the DER value of a company is high, it will influence investors or shareholders to invest their capital in the company. This is because investors prefer a low debt ratio (DER) because the lower the DER value, the greater the level of protection of investors if the company experiences liquidation. This will affect the stock price in the capital market because the higher the DER value, the stock price will decline. 


\subsection{Share Prices}

According to Brigham \& Houston (2006: 408-410) stock prices determine wealth for shareholders. Stock prices from time to time are not constant sometimes experience drastic changes. The stock price will depend on the cash flow expected by the investor if the investor buys shares. According to Hidayat (2011: 103-106) there are five types of stock prices in the capital market, namely:

a. Nominal Price. The nominal price of shares is the price stated on a share issued by a company. This price will be used for recording fully paid capital.

b. Prime Price. The initial price is the price that applies to investors who buy shares during the public offering period. The initial price can be higher or lower than the nominal price.

c. Opening Price. The opening price is the price that will apply when the stock market starts at that time.

d. Market Price. Market price is the price of shares on the stock exchange at that time this will be influenced or determined by demand and supply in the market so that market prices can go up and down.

e. Closing price. The closing price is the stock price at the time of market closing. After opening there in the morning, the afternoon closes and the current price will be the closing price. Thus it can be concluded that the stock price formed in the capital market because of the sale and purchase transactions between the company and investors. When the stock price is closed, the market price is the stock price at the closing (clossing price).

\subsection{Relationship between Earning Per Share, Return on Assets, Price Earning Ratio and Debt to Equity Ratio with Share Prices}

The relationship between EPS, ROA, PER and DER on stock prices is that if EPS, ROA, and PER value is higher then it will be able to influence the desired profit growth will also increase, the higher the value, the higher profits will also mean this means that EPS, ROA, PER and DER have a positive influence on stock prices. Whereas for DER, the higher the DER value, the smaller the level of profits to be obtained by investors, this means that DER has a negative influence on stock prices. This can affect the level of investor confidence in a company.

\subsection{Framework for Thinking}

The research framework is presented in Figure 1 below.

\subsection{Hypothesis}

H1: Earning Per Share has a partial effect on stock prices on Property, Real Estate, Construction and Building companies listed on the Indonesia Stock Exchange in 20162018.

H2: Return On Assets has a partial effect on stock prices on Property, Real Estate, Construction and Building companies listed on the Indonesia Stock Exchange in 20162018.

H3: Price Earning Ratio has a partial effect on stock prices on Property, Real Estate, Construction and Building companies listed on the Indonesia Stock Exchange in 20162018. 
H4: Debt to Equity Ratio has a partial effect on stock prices on Property, Real Estate, Construction and Building companies listed on the Indonesia Stock Exchange in 20162018.

H5: Earning Per Share, Return On Assets, Price Earning Ratio and Debt to Equity Ratio simultaneously influence the stock prices on Property, Real Estate, Construction and Building companies listed on the Indonesia Stock Exchange in 2016-2018.

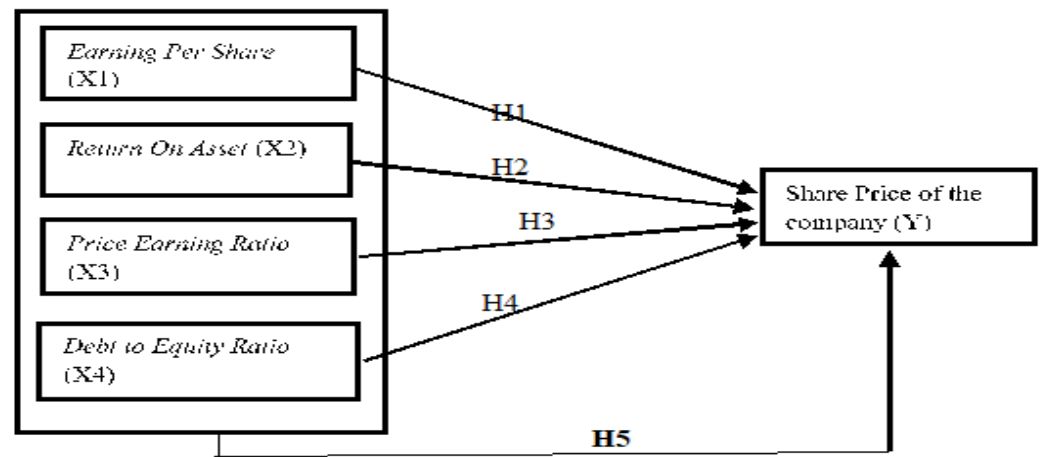

Fig. 1. Framework

\section{Research Method}

\subsection{Research Types, Data Sources, Populations and Samples}

This type of research is quantitative research. According to Ferdinand (2006) quantitative research is research that describes the relationship between independent variables and dependent variables. Sources of data in this study were obtained from the official website of the Indonesia Stock Exchange, www.idx.co.id and the official website of the companies concerned.

The population in this study are Property, Real Estate, Construction and Building companies listed on the Indonesia Stock Exchange (BEI) in 2016 to 2018. The samples used in this study are 55 Property, Real Estate, Construction and Building companies listed on Indonesia Stock Exchange (IDX) for the period of 2016-2018 with 165 financial statements annually. Determination of the sample is done by purposive sampling technique. Purposive Sampling is a sampling technique with certain considerations. The considerations in sampling in this study are as follows:

a. The components contained in the financial statements are very broad in scope, so researchers only choose components related to stocks, namely Earning Per Share, Return On Assets, Price Earning Ratio, and Debt to Equity Ratio.

b. The company has complete data that is needed in this research.

c. Property, Real Estate, Construction and Building companies that have financial statements that end on December 31. 


\subsection{Research Variables and Operational Definition Variables}

a. Dependent Variable (Y). The stock price is the determinant of an investor's wealth and the price of this stock is not constant. The stock price here is the price at the time the price on the Stock Exchange is closed and is called the closing price (clossing price) as the basis for determining the stock price.

b. Independent Variable (X). There are 4 independent variables in this study, namely:

c. Earning Per Share (X1). Represents the profits obtained by the company which will later be given to the shareholders of each share. Earning Per Share can be calculated using the following (1) formula:

$$
\mathrm{EPS}=\frac{E A T}{J s b} .
$$

Information :

EPS $=$ Earning Per Share

EAT $=$ Earning After Tax or income after tax

$\mathrm{Jsb}=$ Number of shares outstanding

d. Return On Asset (X2). Is one indicator that can be used to see the extent of the ability of company assets in generating corporate profits. Return On Assets can be calculated using the following (2) formula:

$$
\text { ROA }=\frac{\text { Net Income }}{\text { Total Assets }} .
$$

e. Price Earning Ratio (X3). It is a comparison between the market price of shares per sheet with the profit of shares per sheet. Price Earning Ratio can be calculated using the following (3) formula:

$$
\mathrm{PER}=\frac{\text { MPS }}{\mathrm{EPS}} .
$$

Information :

PER = Price Earning Ratio

MPS $=$ Market Price Per Share

EPS $=$ Earning Per Share

f. Debt to Equity Ratio (X4). Is the total debt of the company against the total assets owned by the company, the total debt in question is the total current debt and long-term debt (Brigham \& Houston, 2006: 143). Debt to Equity Ratio can be calculated using the following (4) formula:

$$
\text { DER }=\frac{\text { Total Debt }}{\text { Total Assets }} .
$$




\section{Results and Discussion}

\subsection{Test Results of Classical Assumptions}

\section{a) Normality Test based on the Kolmogorov Smirnov Test}

Normality test is a test that aims to determine whether the variables in this study with a regression model can provide a normal distribution or not (Ghozali, 2011: 160). Based on table 1 below, it can be seen that the data is normally distributed. Based on the results of the 2017 SPSS output that the Kolmogorov-Smirnov $\mathrm{Z}$ value is 0.642 and the Asymp results. Sig (2-tailed) 0.805 where this value is greater than 0.05 so it can be concluded that the data are normally distributed.

Table 1. One-Sample Kolmogorov-Smirnov Test

\begin{tabular}{llr}
\hline & & Unstandardized Residual \\
\hline $\mathrm{N}$ & & 165 \\
Normal Parameters & Mean & 0,0000000 \\
& Std. Deviation & 0,42810969 \\
Most Extreme Differences & Absolute & 0,050 \\
& Positive & 0,050 \\
& Negative & $-0,046$ \\
Kolmogorov-Smirnov Z & & 0,642 \\
Asymp. Sig. (2-tailed) & & 0,805 \\
\hline
\end{tabular}

Test distribution is Normal.

Source: processed data (SPSS output)

\section{b) Multicollinearity Test}

The results of the study can be declared free from multicollinearity if the final value results have tolerance $\geq 0.1$ or have a VIF value $\leq 10$ (Ghozali, 2011: 105-106). Based on the results of the multicollinearity test in table 2 below, it can be seen that the tolerance value of EPS is 0.681 ROA of 0.739 PER of 0.901 and DER of 0.991 while the VIF value of each variable is EPS of 1, 469 ROA of 1.353 PER of 1.110 and DER of $1,010$.

Table 2. Multicollinearity Test Results

$$
\text { Coefficients }^{\mathrm{a}}
$$

\begin{tabular}{|c|c|c|c|c|c|c|c|c|}
\hline & \multirow{2}{*}{ Model } & \multicolumn{2}{|c|}{$\begin{array}{l}\text { Unstandardized } \\
\text { Coefficients }\end{array}$} & \multirow{2}{*}{$\begin{array}{c}\begin{array}{c}\text { Standardized } \\
\text { Coefficients }\end{array} \\
\text { Beta }\end{array}$} & \multirow{2}{*}{$\mathbf{t}$} & \multirow{2}{*}{ Sig. } & \multicolumn{2}{|c|}{ Collinearity Statistics } \\
\hline & & B & $\begin{array}{l}\text { Std. } \\
\text { Error }\end{array}$ & & & & Tolerance & VIF \\
\hline \multirow[t]{5}{*}{1} & (Constant) & 2,078 & 0,063 & & 32,909 & 0,000 & & \\
\hline & Earning Per Share & 0,421 & 0,043 & 0,666 & 9,758 & 0,000 & 0,681 & 1,469 \\
\hline & Return On Asset & 0,012 & 0,007 & 0,118 & 1,799 & 0,074 & 0,739 & 1,353 \\
\hline & Price Earning Ratio & 0,005 & 0,000 & 0,238 & 4,004 & 0,000 & 0,901 & 1,110 \\
\hline & Debt To Equity Ratio & 0,000 & 0,001 & $-0,049$ & $-0,858$ & 0,392 & 0,991 & 1,010 \\
\hline
\end{tabular}

a. Dependent Variable: STOCK PRICE

Source: SPSS output 
Based on the results that have been obtained that each variable has a tolerance value of more than 0.10 and a VIF value of less than 10 then there is no Multicollinearity between independent variables so that the regression model is feasible to use.

\section{c) Autocorrelation Test}

In this autocorrelation test is performed to determine testing whether there is a relationship or correlation between the error of the intruder in the period $t$ with the error of the intruder in the period $\mathrm{t}-1$ (the previous one) in the linear regression test model. Testing in this test is using the Durbin-Watson test (DW) (Ghozali, 2011). Based on the autocorrelation results in table 3 above shows the DW value of 1.968 with the independent variable $k=4$ and $n=165$, then the Durbin Watson table obtained a DW value of 1.968 greater du (upper limit) of 1.6960 and less than 2, 2047 which is the result of $4-d u, 4-1.7953=2.2047$, there is no positive or negative autocorrelation, then the regression model can be concluded that no autocorrelation symptoms occur.

Table 3. Autocorrelation Test Results

\begin{tabular}{|c|c|c|c|c|c|}
\hline \multicolumn{6}{|c|}{ Model Summary } \\
\hline Model & $\mathbf{R}$ & R Square & $\begin{array}{l}\text { Adjusted R } \\
\text { Square }\end{array}$ & $\begin{array}{l}\text { Std. Error of the } \\
\text { Estimate }\end{array}$ & Durbin-Watson \\
\hline 1 & $0,702^{\mathrm{a}}$ & 0,492 & 0,479 & 0,43343 & 1,968 \\
\hline
\end{tabular}

a. Predictors: (Constant), Debt To Equity Rqtio, Price Earning Ratio,

Return On Asset, Earning Per Share

b. Dependent Variable: stock price

Source: processed data (SPSS output)

\section{d) Heteroscedasticity Test}

In this heteroscedasticity test conducted to determine testing whether there is an inequality of the residual variance in an observation to another observation in the regression model (Ghozali, 2011: 139).

Tabel 4. Heteroscedasticity Test Results

\begin{tabular}{|c|c|c|c|c|c|c|}
\hline & \multirow{2}{*}{ Model } & \multicolumn{2}{|c|}{$\begin{array}{l}\text { Unstandardized } \\
\text { Coefficients }\end{array}$} & \multirow{2}{*}{$\begin{array}{c}\begin{array}{c}\text { Standardized } \\
\text { Coefficients }\end{array} \\
\text { Beta }\end{array}$} & \multirow{2}{*}{$\mathbf{t}$} & \multirow{2}{*}{ Sig. } \\
\hline & & B & $\begin{array}{c}\text { Std. } \\
\text { Error }\end{array}$ & & & \\
\hline \multirow[t]{5}{*}{1} & (Constant) & 0,317 & 0,037 & & 8,670 & 0,000 \\
\hline & Earning Per Share & 0,025 & 0,025 & 0,095 & 1,004 & 0,317 \\
\hline & Return On Asset & $-0,001$ & 0,004 & $-0,032$ & $-0,353$ & 0,725 \\
\hline & Price Earning Ratio & 0,006 & 0,000 & 0,077 & 0,938 & 0,350 \\
\hline & $\begin{array}{l}\text { Debt To Equity } \\
\text { Ratio }\end{array}$ & 0,000 & 0,000 & $-0,102$ & $-1,299$ & 0,196 \\
\hline
\end{tabular}

A good regression model in this test should not have an indication of heteroscedasticity with results above 5\% (Ghozali, 2011: 142-143). The results of heteroscedasticity test with the Glejser test can be seen in table 4 below. Based on the results of table 4 it can be seen that the 
value of the independent variable is above 0.05 so there are no symptoms of heteroscedasticity. The value of each variable is Earning Per Share (X1) value of 0.317 Return On Assets (X2) is worth 0.725 Price Earning Ratio (X3) is worth 0.350 Debt to Equity Ratio (X4) is worth 0.196 . Because the value of the four independent variables (X) is above 0.05 so it can be concluded that there are no symptoms of heteroscedasticity. Then the regression model used in this study is feasible to use.

\subsection{Hypothesis Testing Results}

Hypothesis test results, summarized in table 5 below:

Table 5. Summary of Hypothesis Test Results

\begin{tabular}{lcccl}
\hline \multicolumn{1}{c}{ Variabel } & $\mathbf{b}$ & $\mathbf{t}_{\text {hitung }}$ & Sig & \multicolumn{1}{c}{ Conclusion } \\
\hline Konstans & 2,078 & & & \\
Earning Per Share & 0,421 & 9,758 & 0,000 & Significantly influential \\
Return On Asset & 0,012 & 1,799 & 0,074 & No significant effect \\
Price Earning Ratio & 0,005 & 4,004 & 0,000 & Significantly influential \\
Debt to Equity Ratio & 0,000 & $-0,858$ & 0,392 & No significant effect \\
Fhitung & & 68,322 & 0,000 & Significantly influential \\
$\mathrm{R}^{2}$ & & & 0,882 \\
\hline \multicolumn{5}{c}{ Source: Data processed with SPSS }
\end{tabular}

\section{a) Multiple Linear Regression Analysis}

Based on the results of the multiple linear regression analysis in table 5, the regression equation (5) can be arranged as follows:

$\mathrm{Y}=2,078+0.421 \mathrm{X} 1+0.012 \mathrm{X} 2+0.005 \mathrm{X} 3+0,000 \mathrm{X} 4$

$$
\begin{aligned}
& \text { Information : } \\
& \mathrm{Y}=\text { share price } \\
& \mathrm{A}=\text { constant } \\
& \mathrm{b} 1-4=\text { regression coefficient } \\
& \mathrm{X} 1=\text { Earning Per Share } \\
& \mathrm{X} 2=\text { Return On Asset } \\
& \mathrm{X} 3=\text { Price Earning Ratio } \\
& \mathrm{X} 4=\text { Debt to Equity Ratio }
\end{aligned}
$$

\section{b) t Test (Partial Test)}

The statistical test $t$ was conducted in this study in order to find out how much influence partially EPS, ROA, PER and DER on Stock Prices. T test results can be seen in table 5 above. Based on the results of the analysis in table 5 above X1 (EPS) shows the value of sig $0,000<0.05$, this shows that the EPS variable has a significant effect on stock prices and EPS tcount of 9.758 and ttable of 1.9749 , then tcount is more large from table 9,758 $>1,9749$ so that $\mathrm{H} 1$ is accepted and $\mathrm{H} 0$ is rejected. It can be concluded that EPS influences stock prices significantly.

Based on the analysis in Table 5 above, the X2 (ROA) results show the value of 0.074> 0.05 , this shows that the ROA variable does not have a significant effect on stock prices and $t-$ 
value of 1.799 and $t$-table of 1.9749 , then $t$ smaller than table $1.799<1.9749$ so H0 is accepted and $\mathrm{H} 1$ is rejected. It can be concluded that ROA does not have a significant effect on stock prices.

Based on the analysis in Table 5 above, the X3 (PER) results show a sig value of 0,000 $<0.05$, this indicates that PER has a significant effect on stock prices, and a t-value of 4.004 and a t-table of 1.9749 , then t large from table 4,004 $>1.9749$ so H1 is accepted and H0 is rejected. It can be concluded that PER has a significant influence on stock prices.

Based on the results of the regression analysis in table 5 above, the X4 result (DER) shows a sig value of $0.392>0.05$, this indicates that the DER does not have a significant effect on stock prices and the t-value of -0.885 and a table of 1.9749 then $t$ count is smaller than table $0.885<1.9749$ so $\mathrm{H} 0$ is accepted and H1 is rejected. It can be concluded that DER does not have a significant effect on stock prices.

\section{c) F Test (Simultaneous Test)}

The $\mathrm{F}$ test was carried out aiming to determine the simultaneous influence on the variable Earning Per Share, Return On Assets, Price Earning Ratio and Debt to Equity Ratio on Stock Prices. Based on the summary results of the hypothesis test table 5 above, it is obtained that sig value $0,000<0.05$ or less than $5 \%$ and Fcount value of 38.757 and Ftable of 2.43 then Fcount is greater than Ftable 38.757> 2.43 so this means that the independent variable Earning Per Share, Return On Assets, Price Earning Ratio and Debt to Equity Ratio simultaneously have a significant effect on the dependent variable namely Stock Prices.

\section{d) Determination Coefficient Test $\left(\mathbf{R}^{2}\right)$}

Testing the coefficient of determination is done to find out how much influence the independent variable Earning Per Share, Return On Assets, Price Earning Ratio and Debt to Equity Ratio on the dependent variable Stock Price. Determination coefficient test results can be seen in the results of the hypothesis test summary table 5 above. Based on the results of the coefficient of determination test in table 5 above shows that the value of Adjusted R Square is $0.479=47.9 \%$, so it can be concluded that the independent variables Earning Per Share, Return On Assets, Price Earning Ratio and Debt to Equity Ratio have an influence of 47.9\% of the dependent variable Stock Price, while $52.1 \%$ is influenced by other variables not examined in this study or examined in other regression models.

\subsection{Discussion of Research Results}

\section{a) Effect of Earning Per Share (EPS) on Stock Prices}

Based on the results of research that has been done that EPS has a significant positive effect on stock prices. The results of the t test can be seen that EPS (X1) shows a sig value of $0,000<0.05$, while for the $t$ value obtained a value of 9.758 is greater than the value of the table with a value of 1.9749 then $\mathrm{H} 0$ is rejected and $\mathrm{H} 1$ is accepted So it can be concluded that EPS (X1) has a positive and significant effect on stock prices (Y).

The results of this study support previous research conducted by Muksal (2016) and Safitri (2013). In a study conducted by Muksal (2016), the P value of 0,000 was obtained below the significance level of 0.05 and the t-value showed a value of 3.873 , this means that EPS has a significant effect on stock prices. Research conducted by Safitri (2013) obtained significance 
results showing a value of $0,000<0.05$ and a tcount of 4.241 , this means that EPS has a significant positive effect on stock prices. While the research conducted by Hijriah (2007) the significance of 0.556 is greater than 0.05 , this means that EPS does not have a significant effect on stock prices.

The results of this study are in accordance with the theory which states that the greater the EPS value of a company, the greater the level of profits that will be obtained by the company's shareholders. With the high value of the company's profits, this will be an attraction for investors to invest in the company. This will affect the company's stock price level. At present investors in investing their capital follow trends in the capital market. So that investor interest in the price of a company's shares is influenced by market behavior. This can be used as a consideration in investing in shares.

\section{b) Effect of Return On Assets (ROA) on Stock Prices}

Based on the results of research that has been done that ROA does not have a significant effect on stock prices. The results of the t test can be seen that ROA (X2) shows a significance value of $0.074>0.05$ while for the tcount shows a value of 1.799 is smaller than the value of the table with a value of 1.9749 , then $\mathrm{H} 0$ is accepted and $\mathrm{H} 1$ is rejected. So this can be concluded that ROA (X2) has no influence on the Stock Price.

The results of this study support previous research conducted by Hijriah (2007) and Safitri (2013). In a study conducted by Hijriah (2007) the results obtained significance value of 0.216 $>0.05$, while the results of the tcount ROA showed a value of -1.254 smaller than the value of this table shows that ROA has no significant effect on stock prices. While the results of research conducted by Safitri (2013) show a significance value of $0.179>0.05$ with a tcount of 1.357 smaller than $t$ table, this shows that ROA does not have a significant effect on Market Prices. While the research conducted by Muksal (2016) is different from the results of research that has been done with the results of the significance value of 0.026 below the 0.05 significance level this means that ROA affects the Stock Price.

The results of this study contradict the theory which states that the greater the value of ROA, the better this will be because the assets owned by the company will spin faster and generate profits. This will increase investor interest in investing in shares. It can be concluded that this shows that in investing investors do not pay attention to the value of ROA as one of the considerations in making investment decisions. Investors do not want long-term profits in the form of dividends, but investors prefer short-term profits, namely capital gains, so investing does not consider the value of a company's ROA.

\section{c) Effect of Price Earning Ratio (PER) on Stock Prices}

Based on the results of research that has been done that PER has a significant effect on stock prices. The results of the t test can be seen that the PER (X3) shows a significance value of $0,000<0.05$ while for the tcount shows a value of 4.004 is greater than the trable value with a ttable value of 1.9749 , then $\mathrm{H} 1$ is accepted and $\mathrm{H} 0$ is rejected. So it can be concluded that PER (X3) has a significant influence on the Share Price.

The results of this study support previous research conducted by Hijriah (2007) and Safitri (2013). In a study conducted by Hijriah (2007), it was obtained a significance result of $0.006<$ 0.05 , this shows that PER has a significant effect on stock prices. While research conducted by Safitri shows a significance value of PER of $0.017<0.05$ with a tcount of 2.433 above the ttable value, this indicates that PER has a significant effect on the Share Price. 
The results of this study are consistent with the theory that the higher the value of PER, the profits generated by the company will also increase. This will benefit a company because it will increase the price of shares in the capital market. Investors will also be interested in companies that have a high PER value because the level of risk possessed by small companies and net income received will be even higher.

\section{d) Effect of Debt to Equity Ratio (DER) on Stock Prices}

Based on the results of research that has been done that DER does not have a significant effect on stock prices. The results of the t test can be seen that the DER (X4) shows a significance value of $0.392>0.05$ while for the tcount shows a value of -0.885 less than the value of the table with a value of 1.9749 , then $\mathrm{H} 0$ is accepted and $\mathrm{H} 1$ is rejected. So it can be concluded that DER (X4) has no influence on the Stock Price.

The results of this study support previous research conducted by Hijriah (2007), Muksal (2016), and Safitri (2013). The results of research conducted by Hijriah (2007) show the results of the t-count of -1.066 smaller than the value of the table and the significance value of 0.292 is greater than 0.05 , thus DER has no significant effect on the Stock Price. The results of a study conducted by Muksal (2016) show a P value of 0.965 above a significance level of 0.05 and the result of a t-count of -0.044 is smaller than the table value, this means that DER has no effect on stock prices. And the results of research conducted by Safitri (2013) show the results of a significance value of $0.967>0.05$ and a t-value of -0.042 , this means that DER does not have a significant effect on stock prices.

This is inversely proportional to the research conducted by Munira, et al (2017) which states that DER has a large influence on stock prices with a significance value of $0.005<0.05$ and a calculated t value of 3.047 greater than the table value.

This is contrary to the theory that says that DER has a large influence on Stock Prices. If the DER value of a company is high, it will influence investors or shareholders to invest their capital in the company. This is because investors prefer a low debt ratio (DER) because the lower the DER value, the greater the level of protection of investors if the company experiences liquidation. This will affect the stock price in the capital market because the higher the DER value, the stock price will decline. This can cause a decrease in investor interest to invest their capital because the rate of return is getting smaller. This will have an impact on the sale and purchase of shares in the Capital Market. If there is a lot of demand or interest from investors in the capital market for company shares, DER will negatively affect the company's stock price.

This makes it possible that investors do not want long-term profits in the form of dividends but rather short-term profits in the form of capital gains. This is to reduce the risk of not returning the capital that has been spent to invest. In this case it means that investors do not use DER as one of the considerations in making investment decisions because the decrease or increase in DER does not affect the Stock Price.

\section{e) The simultaneous effect of EPS, ROA, PER, and DER on Stock Prices}

Based on the results of research that has been done shows that simultaneous EPS, ROA, PER and DER affect the Stock Price. The results of this study indicate a significance value of $0,000<0.05$ and a value of Fcount of 38.757 is greater than the value of $F$ table, with a $F$ table value of 2.43 this means that $\mathrm{H} 1$ is accepted and $\mathrm{H} 0$ is rejected, which means that EPS, ROA, PER and DER has a significant simultaneous effect on stock prices. 
The results of this study support previous research conducted by Hijriah (2007), Munira et al (2017), Muksal (2016) and Safitri (2013). The results of research conducted by Hijriah (2007) show a Fcount value of 6.821 and a Ftable of 2.010 so that the Fcount is greater than Ftable and the significance value of Fcount is $0.000<0.05$, which means that the Fundamental Factors consisting of ROA, ROE, DER, PER, EPS, BV and Systematic Risk simultaneously have an influence on the Share Price. Research conducted by Munira (2017) et al shows a significance value of $0.002<0.05$, this shows that simultaneous ROE and DER affect stock prices. Research conducted by Muksal (2016) shows the Fcount value of 287,255 is greater than the $\mathrm{F}$ table and a $\mathrm{P}$ value of $0,000<0.05$ so that it can be concluded that simultaneous ROA, DER, EPS, BV, Past Stock Prices and Trading Volume influence significantly to stock prices. While research conducted by Safitri (2013) shows a significance value of $0,000<0.05$, this means that EPS, PER, ROA, DER and MVA simultaneously influence the Stock Price.

\section{f) The magnitude of the effect of EPS, ROA, PER and DER simultaneously on Stock Prices}

In this study the results obtained by the coefficient of determination with adjusted R 2 of 0 , 479 or $47.9 \%$. This means that $47.9 \%$ of the Share Price is affected or can be explained by EPS, ROA, PER and DER while the remaining 52.1\% is influenced by other variables not examined in this study or examined in other regression models.

\section{Conclusions and Suggestions}

Based on the results of research analyzes and discussions that have been carried out, the conclusions can be obtained as follows: Partially Earning Per Share (EPS) has a significant effect on the Share Price, it can be seen from the results of $t$ test with a tcount of 9.758 smaller than the table value of 1.9749 and a significance value of 0.000 . The significance value is smaller than the alpha level used which is equal to $5 \%$ or 0.05 . Partially Return on Assets (ROA) has no significant effect on stock prices, this can be seen from the results of the test with a value of 1.799 and a significance value of 0.074 . The significance value is greater than the alpha level used that is equal to $5 \%$ or 0.05 and the calculated $t$ value is smaller than t table that is equal to 1.9749. Partially Price Earning Ratio (PER) significantly influence the Stock Price this can be seen from the results of t test with a value of 4.004 and a significance value of 0.000 . The significance value is smaller than the alpha level used which is equal to $5 \%$ or 0.05. T value of 4.004 is greater than t table that is equal to 1.9749 . Partially the Debt to Equity Ratio (DER) has no significant effect on the Share Price, it can be seen from the test results with a t-count of -0.885 and a significance value of 0.392 . The significance value is greater than the alpha level used which is equal to $5 \%$ or 0.05 . T value of -0.885 is smaller than $t$ table that is equal to 1.9749. Simultaneous that Earning Per Share (EPS), Return On Assets (ROA), Price Earning Ratio (PER), and Debt to Equity Ratio (DER) significantly influence the Stock Price, this can be seen from the Fcount value of 38.757 and the significance value of 0,000 . The significance value is less than $5 \%$ or 0.05 , this means that EPS, ROA, PER and DER affect the stock price. The Fcount value of 38.757 is greater than the F table of 2.43 . 


\section{References}

[1] Brigham, Eugene F., and Joel F. Houston. "Dasar-dasar manajemen keuangan, edisi 11." Jakarta: Salemba Empat (2006).

[2] Darmadji, Tjiptono, and Hendy M. Fakhruddin. "Pasar modal di indonesia." Jakarta: Salemba Empat (2011).

[3] Darsono, Ashari. "Pedoman praktis memahami laporan keuangan." Yogyakarta: Andi (2005).

[4] Fahmi, Irham. "Pengantar Pasar Modal (ketiga)." Bandung: Alfabeta (2017).

[5] Ferdinand, Augusty. "Metode Penelitian Manajemen, Penerbit BP Undip." (2006).

[6] Hijriah, Almas. Pengaruh Faktor Fundamental dan Risiko Sistematik Terhadap Harga Saham Properti di Bursa Efek Jakarta. MS thesis. 2007.

[7] Imam, Ghozali. "Aplikasi analisis multivariate dengan program IBM SPSS 19." Semarang: Badan Penerbit Universitas Diponegoro (2011).

[8] Muhammad, Subana. "Dasar-Dasar Penelitian Ilmiah." (2001).

[9] Muksal, Muksal. "Analisis Faktor-faktor Yang Mempengaruhi Harga Saham Syariah (Studi Pada Pasar Sekunder Jakarta Islamic Index (JII) Tahun 2009-2013)." Jurnal Akad 1.1 (2016).

[10] Munira, Mira, Endang Etty Merawati, and Shinta Budi Astuti. "Pengaruh ROE dan DER Terhadap Harga Saham Perusahaan Kertas di Bursa Efek Indonesia." JABE (Journal of Applied Business and Economic) 4.3 (2018): 191-205.

[11] Safitri, Abied Luthfi. Pengaruh Earning Per Share, Price Earning Ratio, Return On Asset, Debt To Equity Ratio dan Market Value Added terhadap Harga Saham dalam kelompok Jakarta Islamic Index tahun 2008-2011. Diss. Universitas Negeri Semarang, 2013.

[12] Tandelilin, Eduardus. "Analisis investasi dan manajemen portofolio." (2001).

[13] Salemba Empat (2011).

[14] Taufik Hidayat, S. E. Buku Pintar Investasi Syariah. Mediakita, 2011. 